\title{
The Triumph and Anguish of the Russian Revolution: Bessie Beatty's Forgotten Chronicle
}

\author{
Lyubov Ginzburg
}

\author{
... only time will be able to attribute both the political and the \\ social revolution their true values.
}

Bessie Beatty, the Bulletin, 25 September 1917

The centennial of the Russian Revolution celebrated two and a half years ago has been marked by a pronounced revival of interest in its origins and impact upon modern history all over the globe. The occasion presented an opportunity to revisit the unprecedented social and political upheaval that convulsed the country in 1917, defined the world order for much of the twentieth century, and continues to reverberate in Russian national and international politics to this day. Along with countless newly revealed primary sources which have gradually found their way into the public domain, this event has been encrusted with novel meanings spawned within a growing number of discourses previously excluded from historical scrutiny. An example of such a disparity would be an unfortunate slight to gendered narratives in the understanding and interpretation of one of the most controversial social experiments in human history. In spite of the fact that, as with their male counterparts, foreign female correspondents became chroniclers, witnesses, and, in some instances, participants in the thrilling social drama, there have been few references to their representation of the Revolution(s) in its historiography. ${ }^{1}$ Meanwhile, compelled to understanding Russia, while informing com-

\footnotetext{
1 Although disproportionally less than their men-authored counterparts, women's narratives have previously sparked some occasional interest among historians and scholars of journalism and women studies. See for example Ishbel Ross, Ladies of the Press: the Story of Women in Journalism (New York: Harper \& Brothers, 1936), or Zena Beth McGlashan, "Women Witness the Russian Revolution: Analyzing Ways of Seeing," Journalism History 12, no. 2 (Summer 1985): 54-61. The major problem that researchers faced, according to Zena Beth McGlashan, was accessibility. She writes that when journalism historians attempted "to cast about for visions of women's past, the scarcity of materials [became] obvious. ... Women generally did not become either 'superstars' or editors and tended to move between communication-related jobs." That is why, in her view, "the picture of their professional involvement most often lies only with the newspaper and magazine stories they wrote." McGlashan, "Women Witness the Russian Revolution," 59. Recently, in the first decades of the twenty-first century, scholars have rediscovered these unique sources and have increasingly taken more of them into consideration. See for example, Choi
} 
patriots about its culture, politics and the conflicting social milieu, women were equally willing to undergo extraordinary hardships, experiencing the boisterous human joy and direful bitterness that culminated in a revolutionary saturnalia and a civil war. Some recorded their observations for posterity, and it would be a grave mistake to downplay the totality of such narratives, to which no episode or detail is foreign, as women often focus not only on political and strategic developments, but also on everyday life, contributing to a better understanding of what revolutions actually mean, both in terms of changing the socio-economic foundations of a society, and "the physical and emotional experiences of the participants and witnesses."2

Such an assumption is undoubtedly true in regard to an account left by American correspondent Bessie Beatty, one of over a dozen foreign journalists - only a handful of them women - who arrived in the capital of the crumbling empire to report on the history in the making unfolding in Russia "on a much grander scale than anyone in America could ever imagine." 3 Beatty's book and her subsequent publications about Soviet life may be recommended "to all who wish to have an insight into what transpired during the eventful first year of the Russian revolution"4 and its aftermath. As a body of work, they reveal previously underestimated experiences of and reflections upon the fulminant eruption of bitter rivalries, gnawing strife and pervasive suffering, providing a unique personal chronicle of the establishment of a visionary yet impracticable political and economic regime that nevertheless survived for almost three quarters of a century. Her opinion resonated apart from both ardent sympathizers of and believers in the new Soviet regime and its fierce vituperators. Beatty was cautious to suggest that "they were too close [to the events] to see the truth," and that only time would be able to attribute both the political and social revolution their true values. ${ }^{5}$ Unlike many of her countrymen, who shared the same destiny as first-hand witnesses of the historic transformation of Russian society, she was careful not to either laud the Bolsheviks or demonize them. Rather, she firmly believed that the rest of the

Chatterjee, "Odds and Ends of the Russian Revolution," 1917-1920: Gender and American Travel Narratives," Journal of Women's History 20, no. 4 (Winter 2008):10-33, http:// muse.jhu.edu/journals/journal_of_womens_history/v020/20.4.chatterjee.html\#front; Julia L. Mickenberg, "Suffragettes and Soviets: American Feminists and the Specter of Revolutionary Russia," Journal of American History 100, no. 4 (March 2014): 1021-1051; Helen Rappaport's recent volume Caught in the Revolution, Petrograd 1917 (Hutchinson, London: Penguin Random House, 2016) also features a number of female-authored accounts, including by a Canadian Florence Harper, French Amélie Néry, American Rheta Childe Dorr, and Bessie Beatty, among others.

2 Chatterjee, "Odds and Ends of the Russian Revolution," 26.

3 Lisa M. Jankoski, "Bessie Beatty: One Woman's View of the Russian Revolution"

(M.A. Thesis, Villanova University, 1989), 19.

4 Alexander Trachtenberg, "The Red Heart of Russia," New York Call, December 15, $1918,11$.

5 Bessie Beatty, "Around the World in War Time: Russian Masses Climbing from under. History Will Tell of the Revolution that Goes on Today. Not that of Yesterday," The Bulletin, September 25, 1917. 
world should let the Russians themselves determine the fate of their nation and curtail the escalation of fear and hysteria evoked by the Red Scare.

Elizabeth Mary Beatty was born on 27 January 1886, in the Pico Heights district of Los Angeles, the oldest of four children of Irish immigrants, Thomas Edward and Jane Mary (Boxwell) Beatty. Earlier in the decade, Beatty's parents had settled in Iowa, but soon continued their westward journey across America to California. Her father became a director of the first electric street railroad in Los Angeles, prospering until his death in 1902. The family lived in a new suburban development, in the proximity of the Highland Park campus of Occidental College (Oxy), where Beatty matriculated in 1906.

Beatty revealed her passion for becoming a writer early. At Occidental, she majored in English, served as Vice-President of the Witenagemot Literary society, and contributed articles to the school newspaper The Aurora, which later changed its name to The Occidental. In those early experiences with a pen, Beatty espoused the ideals of a youthful feminist. Along with her mother, she was actively involved in the Suffragist movement in California, ${ }^{6}$ where women were granted the right to vote in 1911. Beatty's response to that milestone was an "unpretentious little volume," A Political Primer for the New Voter, published a year later. She dedicated the book to her mother, whom she called "my comrade in the California woman's struggle for the ballot" and "the best in womanhood." With that volume, Beatty, who had already been recognized for her work as a human rights activist and social reformer "far beyond the boundaries of the Golden State," performed "a distinguished public service." ${ }^{8}$ While addressing all three categories of new voters - youth reaching the legal voting age, newly naturalized citizens, and women-Beatty placed special emphasis upon the political and legal status of the latter. John Foster Carr-who himself authored a number of guides to the United States for immigrants - acknowledged a distinct value of Beatty's book that would remain integral to her further writings. He called the spirit of the book "admirable, broadly patriotic with a very persuasive enthusiasm for every good cause," and pronounced the chapters on socialism and the legal status of women as "excellent."

By 1904, while still in college, Beatty secured a position of a drama critic at the Los Angeles Herald, simultaneously managing the so-called women's pages. By 1907, however, "the call of adventure had lured Beatty to the Nevada mining country" to cover a story of labor unrest. She became so interested in her subject, and "so taken with the wild and rugged region," 10 that she quit her job at the news-

6 Norman Cohen, "Bessie Beatty: From Oxy to Heterodoxy," a Faculty Seminar Talk (20 October 1992), Unpublished, 3.

7 Bessie Beatty, A Political Primer for the New Voter (San Francisco: Whitaker \& Ray-Wiggin Co., 1912), frontispiece.

8 William Kent, "Introduction," in A Political Primer for the New Voter, Bessie Beatty (San Francisco: Whitaker \& Ray-Wiggin Co., 1912).

9 John Foster Carr, "A Political Primer for the New Voter. By Bessie Beatty," review of A Political Primer for the New Voter, by Bessie Beatty, National Municipal Review 2, no. 3 (July 1913): 567.

${ }^{10}$ Jankoski, "Bessie Beatty: One Woman's View of the Russian Revolution," 16. 
paper and stayed in Nevada. For the next six months, she lived in a shack near the gold mines, researching and writing a book dedicated to the founders of the state. Entitled Who is Who in Nevada: Brief Sketches of Men Who Are Making History in the Sagebrush State, the volume was published in 1907. The book consists of biographical sketches of "the men of real achievement" behind the unprecedented rapid growth of the state, whom the author calls "unknown heroes of the pick and pan." 11 That a 21-year-old girl was living alone among miners in a frontier town was quite revealing of Beatty's determination to stand up against "ancient fetishes and cherished ideals," 12 crossing into a distinctly masculine realm, whenever it was necessary for her personal and professional interests and advancement.

While in Nevada, Beatty became acquainted with other correspondents from influential California newspapers reporting on the infamous Goldfield Labor Wars - a dramatic outright confrontation between mine-owners and the Western Federation of Miners. Fellow journalists encouraged her to move to the Bay City and try her hand with one of its newspapers. In 1908 she went on a three-week visit to San Francisco where, by the end of her trip, she landed a job with the San Francisco Bulletin, one of the first and most historic of the city's newspapers. It was founded in 1855 by the pioneer crusader-editor James King of William, who "fought the gamblers and politicians and gangsters that ruled early San Francisco." 13 After he was shot to death in front of the Bulletin office by underworld king-pin James Casey, for some time, the valor of the newspaper dissipated. In 1895, however, it was taken over by one of the best reporters in San Francisco, Fremont Older, who became its managing editor, transforming the publication from a "quaking failure to dazzling success." 14 Older radiated an "unquenchable enthusiasm of the crusader," 15 being convinced that good journalism consists of good causes and human-interest stories that go along with them. ${ }^{16} \mathrm{He}$ liked vivid narrative and preferred short sentences, was entranced by the drama behind the news, and projected further story development, enticing readers to anticipate the next issue. He also believed in manufacturing news, but only if it had a social service slant. ${ }^{17}$ Circulation was not 'a golden calf' for the new managing editor, rather it was "a chance to say a little of what he thought ought to be said, it was freedom." 18

Older revolutionized the newspaper, implementing one reform after another. He hired female reporters, believing that women "had more facility of expression than men, were diligent workers, [and] could get anything they wanted." 19

${ }^{11}$ Bessie Beatty, Who's Who in Nevada: Brief Sketches of Men Who Are Making History in the Sagebrush State (Los Angeles: Home Printing Company, 1907), frontispiece.

${ }_{12}$ Bessie Beatty, The Red Heart of Russia (New York: The Century Co., 1918), 91.

${ }^{13}$ Evelyn Wells, Fremont Older (New York: D. Appleton-Century Company, 1936), 90.

${ }^{14}$ Ibid., 90, 115.

${ }^{15}$ Ross, Ladies of the Press, 579.

${ }^{16}$ Robert L. Duffus, The Tower of Jewels: Memoirs of San Francisco (New York: W.W. Norton and Co., 1960), 118.

${ }^{17}$ Ross, Ladies of the Press, 580, 576.

${ }_{18}$ Duffus, The Tower of Jewels, 118.

${ }^{19}$ Ibid., 117, 169-170; Ross, Ladies of the Press, 567; Jankoski, "Bessie Beatty," 17. 
The editor gave many women an opportunity at his newspaper, allowing them to do unheard-of things, and making true crusaders of his female correspondents. ${ }^{20}$ Without a doubt, writing for the Bulletin influenced Beatty's journalistic style, social consciousness and political views. She was one of the writers in which Older fostered "a tendency for radical thought and social reform." ${ }^{21}$ Rather than confining her to women's pages, he entrusted Beatty to cover gender-related matters, along with many other cross-cutting issues in a feature page of her own, "On the Margin." Beatty wrote about the Progressive movement in Washington, graft in Pittsburgh, and life in Alaska. ${ }^{22}$ In 1916, she returned to Los Angeles as a Bulletin correspondent in Hollywood to scrutinize the industry in a series entitled "Behind the Screen - a 'Close-Up' of the Movies in the Making." Beatty was Older's chief ally during his campaign for radical labor organizer Tom Mooney, whose conviction for detonating a bomb during the Preparedness Day parade in San Francisco in July 1916 and his subsequent death sentence were based on fabricated testimony. When the editor declared war on the grafters at City Hall, Beatty stood by the crusader, fighting with the notoriously corrupt "political boss" of San Francisco, Abraham (Abe) Ruef. She also avidly supported Older in his struggle against capital punishment. Simultaneously, Beatty became affiliated with the College of Equal Suffrage League of Non-Partisan Women and appeared in the news for her support for Woodrow Wilson's reelection for president in $1916 .{ }^{23}$

${ }^{20}$ Ross, Ladies of the Press, 580, 576. Older took a personal interest in the talented group of girls, never judging their performance, according to Beatty, on the basis of their sex (Wells, Fremont Older, 219-20). For example, before Beatty's day, Older appointed "a delicate girl" named Virginia Brastow to the post of city editor. For a newspaper that was "in the thick of every fight" throughout those "by no means peaceful" times in San Francisco, a female city editor was quite an experiment (Ross, Ladies of the Press, 583). Another outstanding reporter that would cross into the realm of male journalism was Pauline Jacobson, brilliant daughter of a rabbi, who wrote full-page Saturday articles which were quoted everywhere. She exposed the evils of the city, during the graft crusade, and found her way into the back rooms of saloons, jails, brothels, and every other place "a lady did not go in that age of large hats and long skirts." She was also the first woman to cover sports news in the West, including the famous Gans-Nelson boxing match in Nevada (Wells, Fremont Older, 220). When the war began, Sophie Treadwell, who Older had previously started off on serials, went to France, but could not get anywhere near the front because of her sex, having to accept a position of a nurse in a hospital. Later she would become one of the best-known writers in the country, and a founder of the Lucy Stone League (Ross, Ladies of the Press, 584). Caroline Singer drew readers' attention to the poor working conditions of women in shops and factories (Ibid., 586).

${ }^{21}$ Jankoski, "Bessie Beatty: One Woman's View of the Russian Revolution," 17; Ross, Ladies of the Press, 580.

${ }_{22}$ "Bessie Beatty, 61, Commentator, Dies: Ex-Editor Broadcast Women's Program on WOR-Former Foreign Correspondent," New York Times, April 7, 1947, 23.

${ }^{23}$ United States Congressional Committee on the Judiciary, Bolshevik Propaganda. Hearings before a Subcommittee of the Committee on the Judiciary United States Senate, Sixty-fifth Congress, Third Session and Thereafter, Pursuant to S. Res. 439 and 469. February 11, 1919, to March 10, 1919 (Washington, 1919), 699; Cohen, 4-5. 
For years, Beatty acted as an 'in house social advocate,' hearing the grievances of thousands and attending to many of Older's charitable responsibilities. ${ }^{24}$ She became personally involved in social work, describing her initiatives and their impact on people's lives in a corresponding newspaper series. Beatty launched a successful holiday exchange, dubbed the Red Stocking Campaign, and organized the erection of one of the first outdoor Christmas trees, making four thousand poor children of San Francisco happy. She reported on the state of the city's schools, found homes for unwanted infants, and raised funds for Happyland, a summer camp for underprivileged youth. Over the course of those nine years, that Beatty heralded the "good cause," manifesting compassion and humanism, she won the affection of tens of thousands of readers, becoming the most popular and beloved correspondent on the West Coast." 25

In early 1917, when local clergy induced city authorities to "introduce purity" and "stop vice" by shutting down the red-light district without offering women proper assistance, the Bulletin skirmished on their behalf, castigating the men and the system for profiting from prostitutes' lamentable plight. Beatty was running the campaign in their defense, visiting with the girls, helping them organize the union and find other employment. She interviewed the girls for a series of articles entitled "The Closing of the Line," giving the "young but desperate" women an opportunity to share stories usually muted by stigma, hypocrisy and lust. As in Nevada, and later in Russia, rather than drawing a generalized picture of an impersonal group, Beatty revealed the lives of individuals, thus seeking to stir in her readers a sense of collective responsibility for the girls' predicaments and desolation.

With the news about the revolution in Russia in the winter of 1917 , Beatty decided to go overseas to see firsthand an "amazing experiment in democracy close up" and depict it for the Bulletin's readers. ${ }^{26}$ Infatuated with the great Russian novelists, and having developed a deep appreciation for the country and its people, she saw in such an assignment a great opportunity to observe the conditions under which people were struggling. Beatty persuaded the Bulletin's editor to let her do a series entitled "Around the World in War Time" that would include excerpts from a diary of an American newspaperwoman travelling through belligerent countries. The ultimate goal was to provide coverage of the unfolding revolution, which the Bulletin called "the biggest development of the world war," to endeavor to identify its causes, and "venture a forecast of what the future [had] in store for this newly freed giant among the nations. ${ }^{27}$ Beatty's previous experience as a social advocate, including her unrelenting struggle for the downtrodden, the unfortunate, and the oppressed, ${ }^{28}$ explains her decision to travel to Russia at

${ }^{24}$ Wells, Fremont Older, 271.

${ }^{25}$ Ibid.

26 "Thousands of Miss Beatty's Friends to Watch Her Tour of War-Scarred Countries," Bulletin, April 2, 1917, front page.

27 "Bessie Beatty Leaves on History Making War Time World Tour," Bulletin, April 3, 1917, 20.

${ }^{28}$ Jankoski, “Bessie Beatty: One Woman’s View of the Russian Revolution,” 19. 
"the most dramatic moment of its history." She longed to see how the country was "freeing itself from the bondage, which the [rest of the] world ... [had] accepted as its inevitable and unchanging fate." ${ }^{29}$ In anticipation of her trip, Beatty wholeheartedly supported the "outburst of human freedom and dignity" underway in Russia. ${ }^{30}$ On 2 April 1917, the Bulletin announced Beatty's next-day departure, stating that "her happy and intimate manner of writing, which makes her readers imagine they, too, are spectators of the human drama with which she deals, makes her especially well fitted for this important commission." 31

On 3 April 1917, Beatty boarded the Tokyo-bound steamship Siberia Maru, which sailed through the Golden Gate, launching the thirty-one-year-old American journalist on a journey that would last ten months. The Bulletin published many of Beatty's dispatches from sea, where news of United States entry into WWI reached her, and where she became acquainted with a group of homewardbound Russian expatriates, mostly radicals and socialist-leaning political exiles, returning from America to contribute to and benefit from the social and political changes in their motherland.

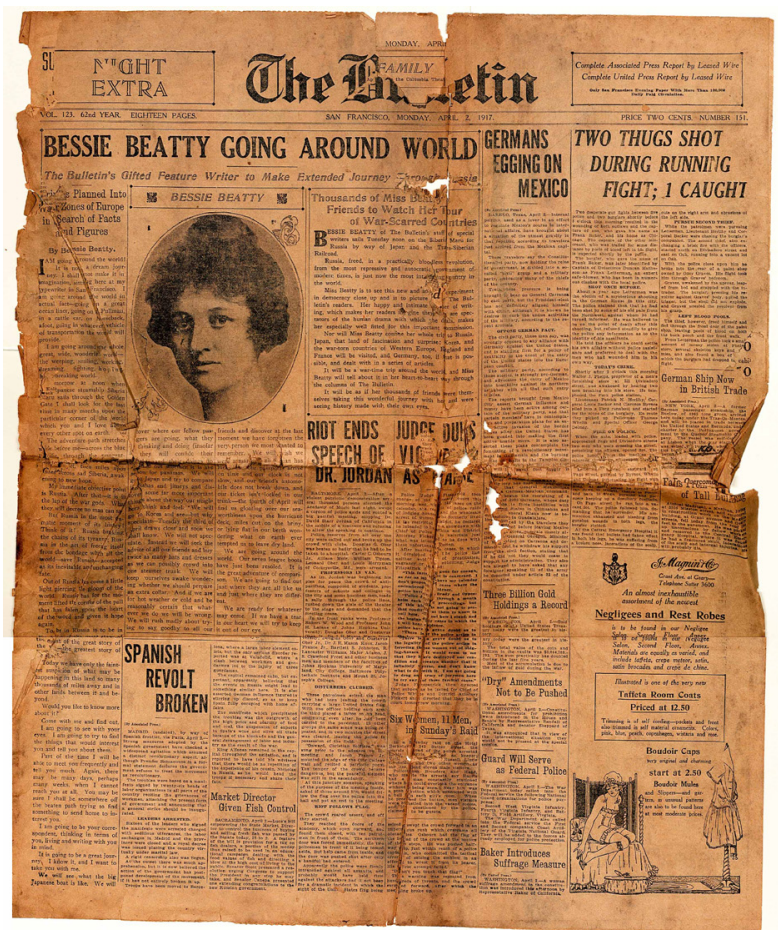

Figure 1. A front page from the Bulletin, 2 April 1917, announcing Bessie Beatty's departure and her assignment to report on revolutionary events in Russia.

${ }^{29}$ Bessie Beatty, "Bessie Beatty Going around the World: Trip Is Planned into War Zones of Europe in Search of Facts and Figures," Bulletin, April 2, 1917, front page.=

${ }^{30}$ Jankoski, "Bessie Beatty: One Woman's View of the Russian Revolution," 19.

31 "Thousands of Miss Beatty's Friends to Watch Her Tour of War-Scattered Countries." 
After a week at sea, the steamer docked at Honolulu, from where Beatty dispatched comments on local schools and governance, as well as on the tragic state of affairs for native Hawaiians, who were "vanishing from [the] adoption of white man's customs." 32 After a few days, Beatty continued her journey to Japan. Upon her arrival in Yokohama, which was "in the throes of an election," she asked to be taken to the polls, thus becoming the first woman that "had ever been inside the municipal building." ${ }^{33}$ In Tokyo Beatty indulged in flower-gazing, and was received by the Minister of Home Affairs, Baron Goto. After an eleven-hour train ride through "Fairyland," Beatty arrived in Kyoto, which she called the "least modern and most picturesque of Japanese cities." ${ }^{34}$ Having visited a few Japanese kitchens, she wrote about traditional gender roles, revealing "personal expressions of inequalities in everyday life." ${ }^{35}$ At the same time, she acknowledged "the desire of [Japanese] women for a broader education and a more Western life," 36 best embodied in the establishment of the Women's University in Tokyo. Beatty interviewed poetess and pioneering feminist Akiko Yosano, and the first Japanese newspaperwoman, Haru Isomura, as well as Moto Hani, the chief editor of a women's magazine with a circulation of 100,000. Her last stop in Japan was Shimonoseki, from where Beatty sailed to Seoul. There she toured opulent imperial palaces and observed local customs, in accordance to which Korean women were considered "less than nothing," playing "no part in [their] husbands' life except as servant[s] and bearer[s] of heirs." ${ }^{37}$ A river steamer brought the American correspondent from Manchuria to Tianjin (Tien-Tsin), China, that was "in the throes of an attack of revolutionary power." ${ }^{38}$ From there, she continued on to Peking — "the great city of walled mysteries," where she was given an audience by the president of the young Chinese Republic, Li Yüan-hung, just a couple of weeks before he was forced to dissolve parliament. After "scratching the surface of political, social, economic and picturesque China," Beatty, with her "reflection on the relativity of things," was ready to penetrate "deeper and deeper into the heart of the unknown." 39

${ }^{32}$ Bessie Beatty, "Bessie Beatty Letters: Around the World in War Time," Bulletin, May 21, 1917, 5.

${ }^{33}$ Bessie Beatty, "Bessie Beatty Letters. Around the World in war Time," Bulletin, June 4, 1917, 4.

${ }^{34}$ Bessie Beatty, "Descriptive Letters of the Happenings in Many Lands Since the Beginning of the Struggle for Democracy. Around the World in War Time," Bulletin, June 23, 1917, 5 .

${ }^{35}$ Ibid.

${ }^{36}$ Bessie Beatty, "Descriptive Letters of the Happenings in Many Lands since the Beginning of the Struggle for Democracy. Around the World in War Time," Bulletin, July 2, 1917, 16 .

${ }^{37}$ Bessie Beatty, "Descriptive Letters of the Happenings in Many Lands Since the Beginning of the Struggle for Democracy. Around the World in War Time," Bulletin, July 11, 1917, 9 .

${ }^{38}$ Bessie Beatty, "Descriptive Letters of the Happenings in Many Lands Since the Beginning of the Struggle for Democracy. Around the World in War Time," Bulletin, July $18,1917,8$.

${ }^{39}$ Bessie Beatty, "Around the World in War Time: From Pekin to Petrograd. Excerpts from the Diary of an American Newspaperwoman," Bulletin, July 27, 1917, 5. 
While Beatty's travels through Hawaii, Japan, Korea and China were not described in the The Red Heart of Russia, they were Bulletin page-turners, preparing readers for her final destination-revolutionary Petrograd. On 31 May, Beatty boarded a train bound to Mukden, en route to Harbin, to make connection with the Trans-Siberian Railroad - the world's longest. On 1 June, she wrote from Changchun: "Harbin is only an hour distant. ... at 10 o'clock the express is due to pick me up and pack me off through Asia into Europe." ${ }^{40}$ During her trip, Beatty was enthralled by "unthinkably vast" Siberia, and concluded that it was anything but a dreary, desolate waste. For five hours, she was contemplating Lake Baikal, surrounded by great mountains, and went through tunnels "no less than forty-one times." She stopped in Irkutsk, a goldmining center developed and built by prisoners and political exiles, and passed through Krasnoyarsk, the resting place of Russian nobleman Nikolai Petrovich Rezanov, a betrothed of a daughter of San Francisco Precidio commandante, known and fancied by "lovers of California romance". ${ }^{41}$ As the train approached European Russia, Beatty witnessed a growing number of solders travelling in the opposite direction from the front, and encountered workers' and soldiers' deputies of the All-Russian Central Executive Committee, sent to the provinces to protect the victories of the Revolution and spread revolutionary propaganda. Overall, the cross-country trip proceeded without major mishap and was "only four hours off schedule!" 42

On Sunday morning, 10 June 1917, the American correspondent finally arrived at Petrograd, which after ten "long, hot, dusty days" on board the train, appeared "strange, mysterious, inscrutable, [and] compelling." 43 Thanks to "three good Samaritans" and a pinch of luck, Beatty found a room at the famous Astoria Hotel, named in honor of the renowned New York hoteliers, the Astor brothers. Opened in 1912, in preparation for observances of the $300^{\text {th }}$ anniversary of the Romanov dynasty on the Russian throne, during the war the Astoria was in the hands of the military, acquiring the nickname the "War Hotel." It was situated in the heart of the city, in proximity to Nevsky prospekt, its principal thoroughfare, and close to the Mariinsky Palace, the seat of the Provisional Government until July 1917, as well as the Winter Palace, where Kerensky's second coalition government relocated that summer. After members of his cabinet were arrested by the Bolsheviks in October, the hotel became an epicenter of the power struggle between combatting revolutionary forces. As it routinely changed hands, Beatty witnessed the Battalion of Death quartered there one day, replaced by a detachment of Red sailors the next, before being taken over by cadets, then retaken by the Bolsheviks again. Despite the fact that it was "a beacon for foreign visitors," including prominent statesmen and high-ranking military personnel of allied armies, the hotel was not protected in any way from uncertainty, perpetual esca-

${ }^{40}$ Ibid.

${ }^{41}$ Bessie Beatty, "Around the World in War Time: From Peking to Petrograd. Excerpts from the Diary of an American Newspaperwoman," Bulletin, August 3, 1917, 18.

${ }^{42}$ Bessie Beatty, "Around the World in War Time: From Peking to Petrograd. Excerpts from the Diary of an American Newspaperwoman," Bulletin, August 6, 1917, 4.

${ }^{43}$ Beatty, The Red Heart of Russia, 3. 
lation of tensions and occasional eruption of dire confrontation between various groups divided by centuries of conflicting interests and deeply-rooted irreconcilable discord.

Over the eight months that Beatty spent in Petrograd, her own "little blueand-white room on the sixth floor" of the Astoria would become "a base of operations," an idiosyncratic refuge from an overpowering reality fraught with human frenzy that in those revolutionary days would lay too "close to the surface." 44 It was her escape upon return from the front, where she had sloshed through Russian trenches within a hundred-and-sixty-feet of enemy dugouts, and after a week spent in barracks with women soldiers of the Battalion of Death. It was in Beatty's little blue room where one of the infamous Cheka 'troika,' Jake Peters, brought the Decree of Peace to be translated into English. When Beatty was repeatedly urged to leave the hotel and find refuge under the auspices of the American Embassy or elsewhere by "kindly members of the American colony bent on rescuing [her] from the storm-center of Revolution," 45 she preferred to remain under that very roof in order to witness close-up "the tremendous revolutionary drama, involving the destiny of nearly two hundred million Russians and no one could say how many others of the peoples of the world." By the scale of the immensity of the event, personal security seemed to Beatty "a trivial thing." 46

Beatty arrived in Petrograd in time to witness major developments that would eventually lead to the Bolshevik uprising. She was there to observe the consequences of the unsuccessful military offensive launched by Kerensky in late June 1917, and the July Crisis that followed, leading to a temporary decline of Bolshevik influence. During the Kornilov Affair in August, Beatty was at the Astoria Hotel, collecting opinions from people "with various degrees of political belief, ranging from princes suspected of monarchistic tendencies to the most radical of the radicals. ${ }^{~} 47$ While many of her interlocutors, such as English suffragist Emmeline Pankhurst, believed that Russia needed "a strong hand," and that "only Kornilov could save the situation," Beatty felt that "the masses would regard any attempt to install a dictator as an attack on their [revolution] and would desert the man responsible for it." ${ }^{48}$ Although her prediction proved correct, and "the first attempt to install a man on horseback" ended in fiasco, the Kornilov adventure would have other, more dramatic consequences. It would drive "the radical forces further and further to the left," creating a mass solidarity "fatal to the existing order" ${ }^{49}$ and paving the way for the ascendency of the Bolsheviks and their leader, whom Beatty christened the "Dictator of All the Russias."

Beatty's attitude regarding the rapidly growing power of the Bolsheviks was inconclusive, at least as she drafted dispatches for the Bulletin. Although she gained a reputation as a Bolshevik sympathizer after testifying before the US Sen-

\author{
${ }^{44}$ Ibid., 324. \\ ${ }^{45}$ Ibid., 323. \\ ${ }^{46}$ Ibid., 242. \\ ${ }^{47}$ Ibid., 154. \\ ${ }^{48}$ Ibid., 148. \\ ${ }^{49}$ Ibid., 163. \\ ${ }^{50}$ Bessie Beatty, "Lenin Dictator of All the Russias," Bulletin, January 3, 1918, 7.
}




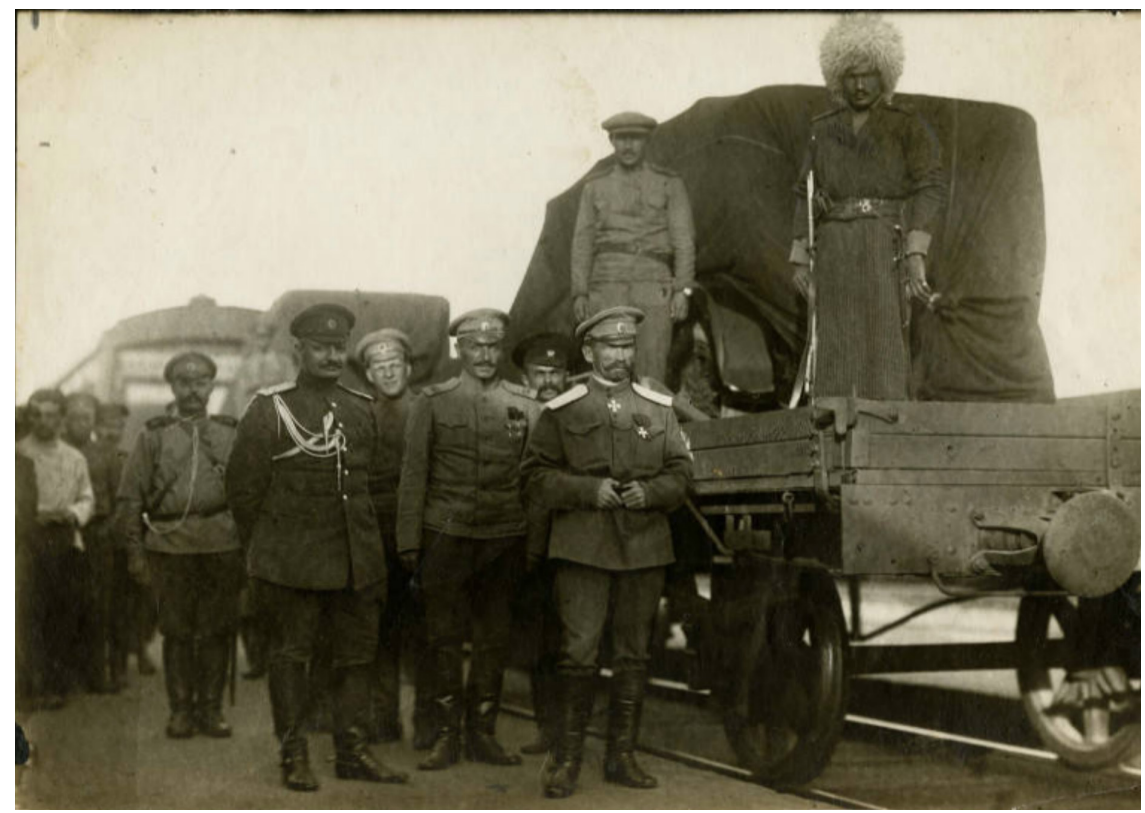

Figure 2. L. G. Kornilov, his staff and Cossack from the "Wild Division", from Bessie Beatty, The Red Heart of Russia (New York: Century Co, 1918), 172.

ate Overman Committee in the spring of 1919, it would be an oversimplification to suggest that Beatty was an ardent hard-shell supporter of the Soviet regime. Rather she came to resent the escalation of public anxiety and frenzy, as well as demonization of the liberal ideas of revolutionaries and Russians themselves, evoked by the hearing. She never claimed she was partisan "in her feelings or in sympathies" with the Bolsheviks. Responding to Senator Overman, she stated: "I'm merely an observer of Russian affairs. My feeling is that we ought to understand what produced the Bolsheviks, what they are trying to do, what there is that is good about them, and what there is that is bad." ${ }^{51}$ During the July Days, when "Petrograd [lay] terrified and trembling in the hollow of the Bolsheviks hand," she produced a reprehensible image of the Bolsheviks as "the party of chains," whose roots were "buried deep down in the black past of Russia." ${ }^{53}$ She urged that they be distinguished from the Council of Workmen's and Soldiers' deputies and the masses, describing the Bolsheviks as "pitiful little fellows, with just enough ignorance, just enough idealism, just enough knowledge of the catchwords of economics" to miraculously defeat "every other power in Russia" in practically no time. ${ }^{54}$ As the culmination of the ultimate political and social upheaval of un-

${ }^{51}$ United States Congressional Committee on the Judiciary, Bolshevik Propaganda, 702.

${ }^{52}$ Beatty, The Red Heart of Russia, 121.

${ }^{53}$ Bessie Beatty, "Bessie Beatty, Caught in Street Battle, Tells of Petrograd's Bloodiest Sunday," in Bulletin, August 25, 1917, 7.

${ }^{54}$ Ibid. 
precedented scale approached, Beatty was overwhelmed by developments, anticipating detrimental consequences following any attempt to abruptly usurp power, fearing more inevitable yet unnecessary losses of human life. Fleeing importunate rumors about impending terror and shrugging off the sensation of death that "was in the air," she took refuge in her blue-and-white room, where she "drew the curtains, turned on all the lights, and curled up on the couch to bury [herself] in a book of verse and shut [the Revolution] out". ${ }^{55}$ Yet even when "urged to quit the capital," ${ }^{6}$ Beatty remained at her journalistic post, fulfilling the promise "to find something to send home to interest [her readers]." 57

"Trying honestly and sympathetically to understand all of the forces at work in the Revolution," ${ }^{58}$ Beatty became acquainted with a wide range of people, from the noblest holdovers from the tsarist regime to Bolshevik leaders, including Alexandra Kollontai, Leon Trotsky, and Lenin himself, whom she briefly met in January 1918, before interviewing him during a visit to Russia in 1921. She developed the habit of dropping in on the seventy-three-year-old "babushka" of the Russian Revolution, Ekaterina Breshko-Breshkovskaia, visited imprisoned members of the Provisional Government in the Peter and Paul Fortress, and attended the trial of Countess Sofia Panina, the Deputy of the Minister of Social Welfare and Education in the Provisional Government, who refused to turn over funds to the Bolsheviks. Beatty approached the war and the Revolution in an intimate and humanitarian way. She rendered human affairs in their diversity and naturalness, exploring historic events through the quotidian experiences of participants, using their personal stories as sources of information. For two weeks, she shared a sleeping platform with Maria Bochkareva, the commander of the legendary Battalion of Death, revealing female warriors' unique sorrows, concerns, and fears. Having attended three national peasants' conventions, Beatty described them through the unflagging fervor of the delegates seized by "the force and fire of a spirit" ${ }^{\prime 59}$ of little peasant General Maria Spiridonova.

On the fateful night of 25 October, along with "poet of the revolution" John Reed, bohemian feminist Louise Bryant, Christian socialist Albert Rhys Williams, and Russian-American expatriate Alexander Gumberg, Beatty was at the epicenter of events. Going first to Smolny, where they attended the Second All-Russian Congress of Soviets of Workers' and Soldiers' Deputies, and later to the Winter Palace, they witnessed the arrest of the Provisional Government, becoming chroniclers of events that would change the course of world history. As with many other developments comprising the Russian Revolution, Beatty humanized its denouement, placing in the spotlight the arrested members of Kerensky's cabinet, whose unabashed emotions emerged from under the guise of governmental officials entrusted with the fate of a hundred and seventy million people. They were stunned,

${ }^{55}$ Beatty, The Red Heart of Russia, 179.

${ }^{56}$ Bessie Beatty, "Bessie Beatty Faces Danger at Petrograd," Bulletin, November 14, $1917,18$.

${ }^{57}$ Bessie Beatty, "Bessie Beatty Going around the World: Trip Is Planned into War Zones of Europe in Search of Facts and Figures," Bulletin, April 2, 1917, front page.

${ }^{58}$ Beatty, Red Heart of Russia, 138.

${ }^{59}$ Ibid., 366. 
as was Petrograd, in the realization that with their surrender the dictatorship of the proletariat had become fact.

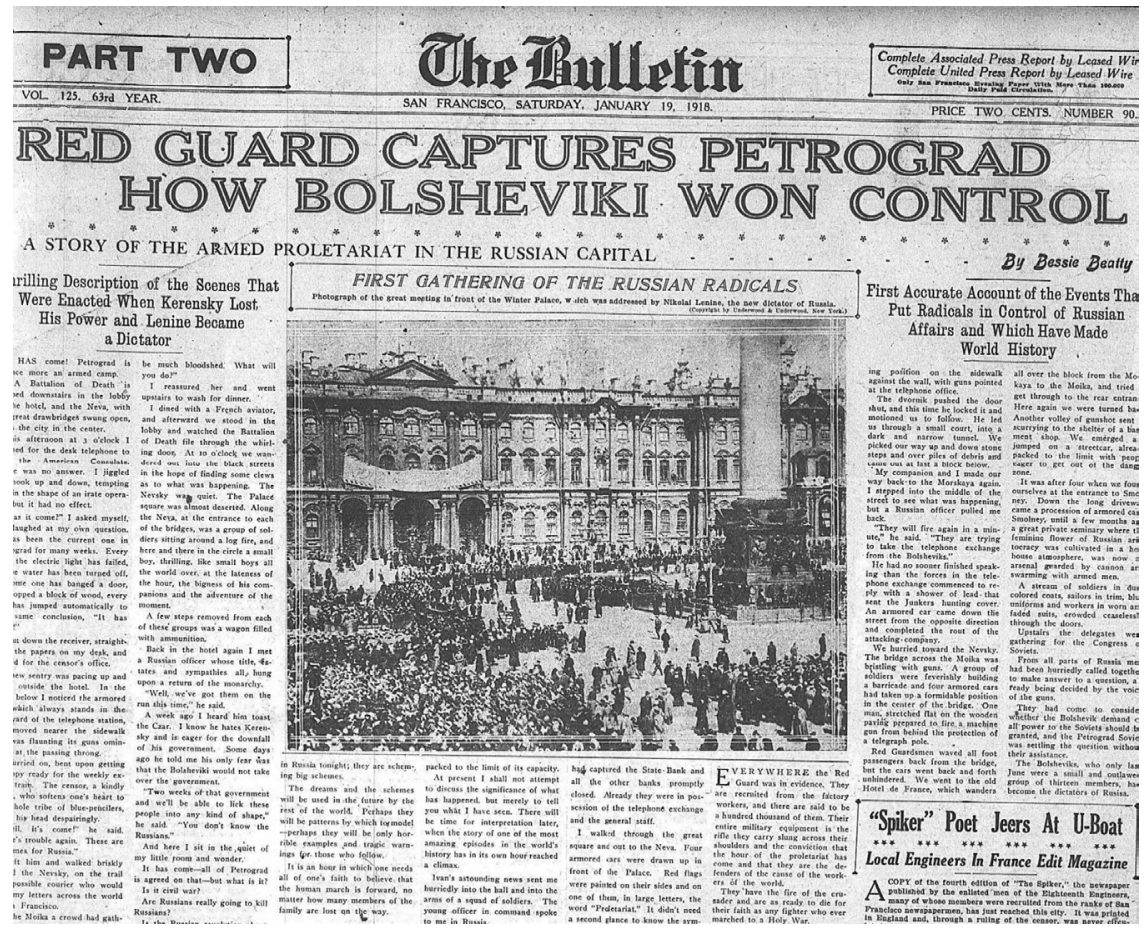

Figure 3. A section cover of the Bulletin, 19 January 1918, with Beatty's report and analysis of the Bolsheviks' seizure of power in October 1917.

Meanwhile, at the other end of the spectrum, Beatty depicted another array of feelings. "Exhausted by lack of sleep, depressed by the rejection of intelligentsia," the Bolsheviks remained in disbelief of the degree of their success, which was greater than they expected. ${ }^{60}$

The climax of Beatty's eight months in revolutionary Russia was the convocation - and almost immediate dissolution — of the Constituent Assembly. When it met on 5 January 1918 at the Tauride Palace "under the Bolshevik guns," Beatty was there to experience its entire twelve-hour lifespan. A failed attempt to implement the Enlightenment notions of "popular sovereignty" and unify all sectors of Russian society shattered Beatty's initial enthusiasm for the "amazing experiment in democracy." She lamented the lost hope for Russia's constitutional development, with the Bolsheviks unilaterally overthrowing a legitimate representative organ of elected people's deputies and reversing the impulses of the February Revolution. "Born and vanished in bloodshed," the Constituent Assembly contained, according to Beatty, "the seeds of the greatest government possibility ever

${ }^{60}$ Ibid., 220-21. 
placed in the hands of a body of dreamers, but they scattered them upon the rocks of stubbornness and misunderstanding, and there could be no harvest." ${ }^{\prime \prime 1}$

As Beatty was leaving Russia on 26 January 1918, she saw the apprehension in people's eyes and felt that "tragedy was in the air." 62 She anticipated devastating consequences of one-party monopoly on power, predicting the imminent terror. As Petrograd, "wrapped in the gray morning mist," gradually slipped from view, it seemed that "Russia, which had touched the heights and the depths, had at that moment found the bottom of her cup of misery." That day, she knew that Russia "had only begun to suffer."63

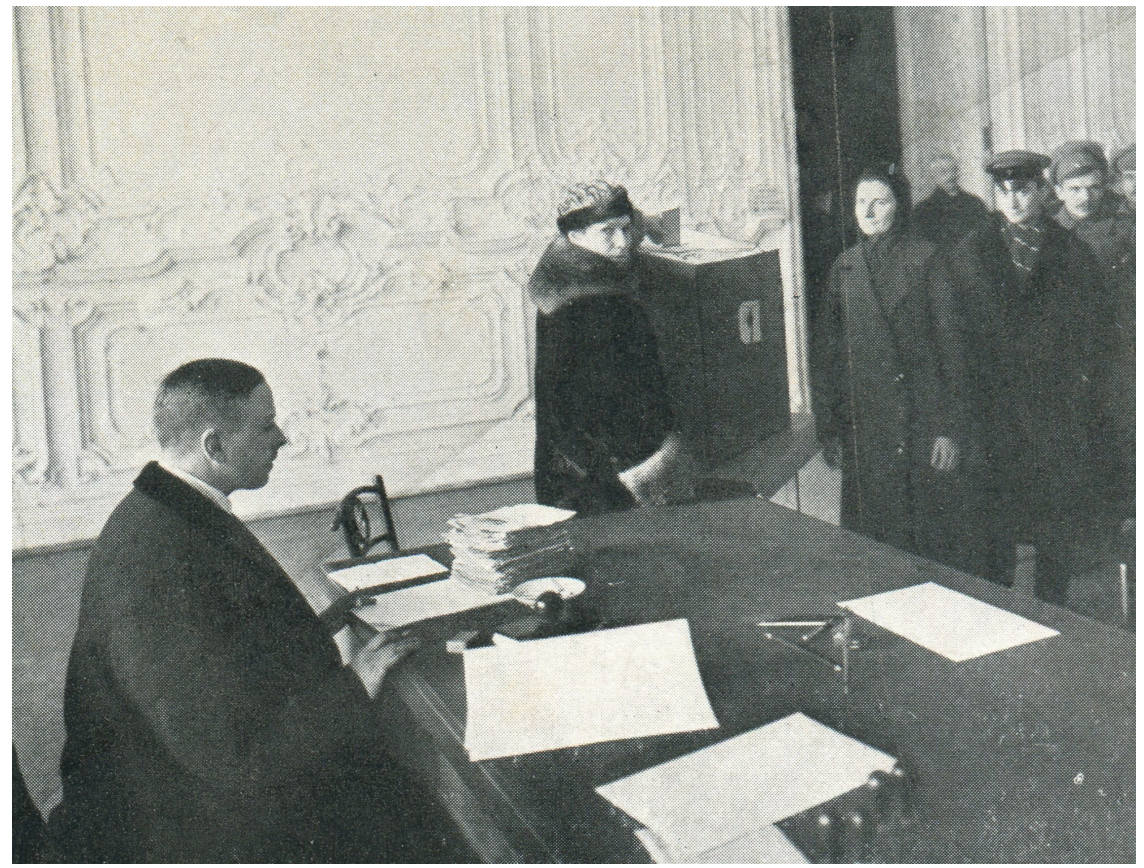

Figure 4. New Russia votes for the Constituent Assembly, from Bessie Beatty, The Red Heart of Russia (New York: Century Co, 1918), 401.

Back in the United States at the end of February 1918, Beatty conveyed her adventure in a volume entitled The Red Heart of Russia, published that year and largely well-received. ${ }^{64}$ Her book appeared in print prior to John Reed's Ten Days

${ }^{61}$ Beatty, "Bessie Beatty's Story of Russian Catastrophe," Beatty, The Red Heart of Russia, 428.

${ }^{62}$ Beatty, Red Heart of Russia, 478; Bessie Beatty, "Bessie Beatty Tells of Russian Tragedy," Bulletin, March 2, 1918, front page.

${ }_{63}$ Beatty, "Bessie Beatty Tells of Russian Tragedy."

${ }^{64}$ See for example "Beatty, Bessie, Red Heart of Russia," The Book Review Digest, fourteen annual cumulation, reviews of 1918 books, ed. Mary Katharine Reely (New York: H. W. Wilson Company, 1919), 35; "Beatty, Bessie, Red Heart of Russia," The Booklist: A Guide to the Best New Books, vol. 15, October, 1918-July, 1919 (Chicago: American 
that Shook the World, and according to scholars who are intimately familiar with her literary and historic legacy, it was as valuable as and "in some way [even] better" than the more sensational account by her fellow correspondent. ${ }^{65}$ Yet, while Reed's work has remained a must-read for anyone interested in the era of the Russian Revolution, Beatty's writing until very recently has been "shunned" into obscurity, largely due to the established credibility of male-dominant mainstream media constructs and gender-biased trends in historiography. Additionally, Beatty's reportage turned out to be less provocative, as, unlike Reed, Williams or Bryant, she was neither committed to the promotion of a political cause nor to presenting herself as a radical outsider. ${ }^{66}$

As in the gold mines of Nevada and the underworld of San Francisco, Beatty remained resolute in pursuing "stories of human interest," whether in the streets of revolutionary Petrograd, in No Man's Land on the Eastern Front, or in the barracks of the Women's Battalion of Death. Her socially- and culturally-enhanced narratives presented the Russian Revolution in a light that sharply contrasted with the unchallenged political discourse that dominated front-page newsprint. While the nation's newspapers ran blaring headlines of breaking news, rarely would they provide insight into driving forces behind historic developments or situate primary actors in their respective settings. Beatty, on the other hand, would breathe life into her dispatches, unravelling the gradual escalation of events and depicting underlying circumstances that she would often experience firsthand. Her columns would appear more dynamic and resonant than the daily "straight news" with their "tedious lists of official sources, rumors, innuendoes and occasional facts." ${ }^{967}$ In many instances, she would postulate prophetic suppositions, which, as with many other gendered analyses of the revolution, would remain unnoticed and uncredited. Thus, when the front pages of the Bulletin reported Russia's official affirmation of its fidelity to the Entente allies and subsequent rioting by "armed mobs" demanding the resignation of the Provisional Government Foreign Minister Pavel Nikolayevich Miliukov, ${ }^{68}$ nothing was mentioned about the centuries-long deep-rooted causes of the unrest, so vividly depicted in Betty's dispatches, and later in her book. As a Wilsonian supporter, she understood the necessity of combatting "the arch-enemy of liberty and peace, ${ }^{, 69}$ but as a humanist, she could never accept the heavy toll of war paid by millions. Breaking from the "gentleman's agreement" that ruled in couloirs of the ministry or the Winter Palace headquarters of the Root Mission,

Library Association Publishing Board, 1918-19), 99; "Russia as Seen by Americans," The Nation (16 November 1918): 591.

${ }^{65}$ Cohen, "Bessie Beatty: From Oxy to Heterodoxy," 7; McGlashan, "Women Witness the Russian Revolution," 57.

${ }^{66}$ Cohen, "Bessie Beatty: From Oxy to Heterodoxy", 10-11; Jankoski, "Bessie Beatty: One Woman's View of the Russian Revolution," 8.

${ }^{67}$ McGlashan, "Women Witness the Russian Revolution," 59.

68 "Russia Affirms Fidelity," Bulletin, May 3, 1917, front page; "Armed Mobs Rise Against the Ministry," Bulletin, May 4, 1917, front page; "Demand Made that Miliukov Resign Office," May 4, 1917, front page.

${ }_{69}$ Beatty, Red Heart of Russia, 65. 
where she found herself among half a dozen foreign correspondents as "an occasional" reluctantly admitted lady, ${ }^{70}$ Beatty reported from "the street corners," "the crowded trams," "the wide paths of the parks," and from trenches filled with the sloshing red mud. ${ }^{71}$ She would populate her dispatches with "armless, legless, blind and broken men," 72 punctuate her stories with "shuttered bones and tortured flesh," entangling the pages with zigzags of barbed-wire and making them reek with "the terrible stench of gangrene." "A3 And while the front pages allocated space for Miliukov's statement that "never shall Russia consent to a separate peace,"74 Beatty would explain why the Root Mission's attempt to persuade Russians to stay in the war failed, and why "the diplomates from Hester Street" succeeded in preaching to thousands of men confined to trenches, who were beyond tired of fighting. ${ }^{75}$ Beatty lamented the total deprivation of human dignity, rendering in her gripping narrative "the dirt, the flies, the vermin, the monotonous round, the endless soup and kasha, the waiting," all those things "that took the last ounce of a man's courage and faith." ${ }^{, 76}$ She would be outspoken about ranks of Russian soldiers who "chose to be shot as cowards and traitors" rather than continue fighting. ${ }^{77}$ Beatty concluded that although tragic, mass desertion was inevitable. ${ }^{78}$

Trying to decipher the convoluted social strife unfolding against a backdrop of the Great War, Beatty brought individuals to the fore of her accounts, which transcended public domain and explored domestic sanctuaries, intertwining personal acts with social consequences. Thus, after visiting the front and sharing bed and bread with the female warriors, the humanist prevailed, and Beatty denounced the continuous human suffering by describing the anguish of a sobbing wounded German, ${ }^{79}$ the lust for blood pervading a young woman soldier murdering another human being who, by will of fate, happened to be in the camp of the enemy, ${ }^{80}$ or

${ }^{70}$ Ibid., 37.

${ }^{71}$ Ibid., 34, 81.

${ }^{72}$ Ibid., 20; Bessie Beatty, "Around the World in War Time: A Friend in a Strange Land. Excerpts from the Diary of an American Newspaperwoman," Bulletin, August 16, $1917,8$.

${ }^{73}$ Beatty, Red Heart of Russia, 73, 62; Bessie Beatty, "Two Weeks on the Russian Front. Dodging Shrapnel as an Enemy Air-Fighter Flies over Camp," Bulletin, October 4, 1917, 4; Bessie Beatty, "Two Weeks on the Russian Front. Watching the Big Guns Crumple the Trenches of the Foe," Bulletin, October 5, 1917,10; Bessie Beatty, "Two Weeks on the Russian Front. Baba-Yagas Shriek as San Francisco Girl Stands within 150 Feet of German Lines. A Description of the Slavs Grim Determination to Win," Bulletin, October 6, 1917, 13.

74 “Miliukov Bravely Tells Mob Russia Will Keep Faith," Bulletin, May 4, 1917, front page.

${ }^{75}$ Beatty, The Red Heart of Russia, 42.

${ }^{76}$ Ibid., 83; Beatty, "Two Weeks on the Russian Front. Baba-Yagas Shriek as San Francisco Girl Stands within 150 Feet of German Lines.”

${ }_{77}$ Beatty, The Red Heart of Russia, 45.

${ }^{78}$ Ibid., 83.

${ }^{79}$ Bessie Beatty, "Two Weeks on the Russian Front: An Interview with a Boy Prisoner Taken from a German Scouting Party," Bulletin, October 8, 1917, 9.

${ }^{80}$ Beatty, The Red Heart of Russia, 111; Bessie Beatty, "The Woman Soldier. Battalion of Death Formed by a Soldier" Bulletin, November 28, 1917, 18. 
the senseless agony and death of a twenty-year-old Russian boy, who embodied "all the boys in the world" dying "in the years of [their] strength and youth, alone and far from home." ${ }^{81}$ Human lives, conditioned by perpetual economic, political and social vicissitudes, would remain at the core of Beatty's writings, public speaking and broadcasts throughout her career as a journalist, a defender of human rights and social justice, and an advocate for unity among sovereign nations.

While expressing hope for Russia, Beatty had no illusions with regard to the social and political changes she witnessed. The rise of the Bolsheviks altered the course of the Revolution and the story of the "great experiment in democracy" that she intended to report on. She would consider every new development as a trial, doubting that the forces behind them were aware of outcomes. There was "no other place," wrote Beatty, that would be so "full of hope and heartache, of human possibility and impossibility, of blundering, groping children, struggling to climb toward the light and losing their way hopelessly in the dark." 82 Having no political affiliation of any kind, either in the United Sates or Russia, Beatty refused to impose premature conclusions, and instead 'streamed live' the revolution in the making and its aftermath. Her account is neither anti-Bolshevist "bourgeois invectives," nor "panegyrics to the new order." ${ }^{33}$ She relayed events pronouncing no judgments, a task that she left for the next generation of historians, political observers and social advocates.

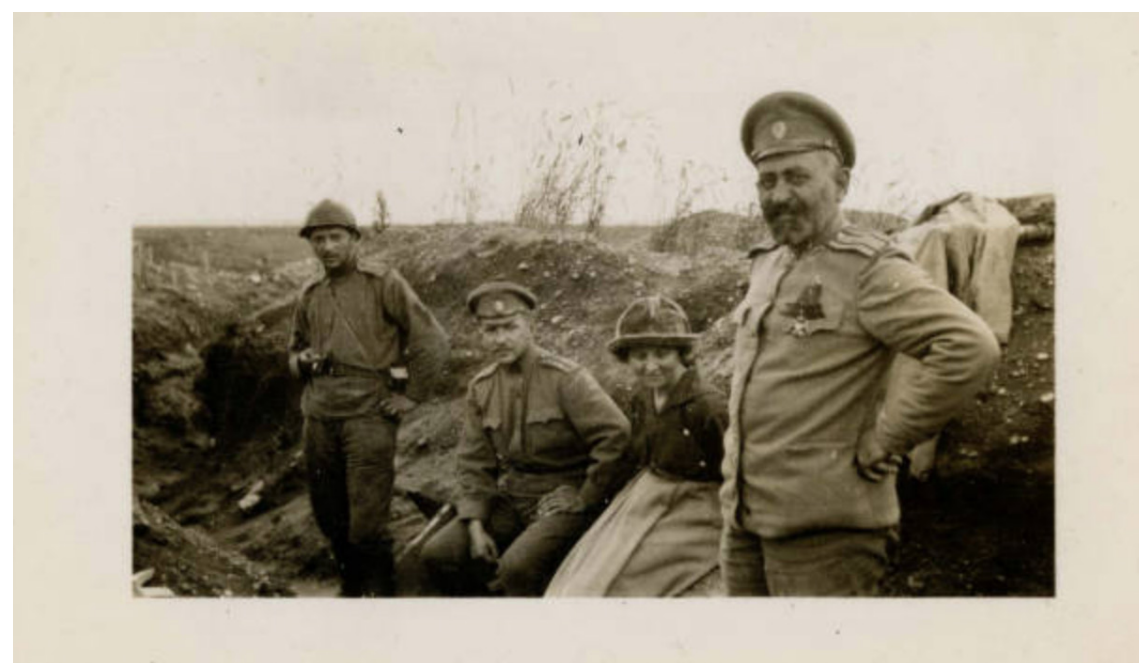

Figure 5. Bessie Beatty in the trenches with two officers and a soldier of the Russian Army. 1917. Courtesy of Occidental College and the Beatty Family.

${ }^{81}$ Beatty, The Red Heart of Russia, 78; Bessie Beatty, "Two Weeks on the Russian Front: In the Trenches with the Fighting Men of the New Republic," Bulletin, October 9, 1917, 9 .

${ }^{82}$ Bessie Beatty, "Around the World in War Time. Russian Masses Climbing from Under. History Will Tell of the Revolution That Goes on Today, Not That of Yesterday," Bulletin, September 25, 1917, 4.

${ }^{83}$ Jankoski, "Bessie Beatty: One Woman's View of the Russian Revolution," 11. 
Beatty never returned to the San Francisco Bulletin. She settled in New York, where she became an editor of McCall's Magazine, a women's monthly, and delivered lectures on Russia, calling for an immediate end to American intervention there. Along with Louise Bryant, Beatty made an appearance before the radical feminist New York Heterodoxy Club, of which she was a member, giving a shared talk on her experiences in Petrograd.

Beatty saw her fears realized, upon returning to Russia in 1921, and spending nine more months as a correspondent for Good Housekeeping and Hearst's International. She interviewed Vladimir Lenin, Leon Trotsky, and People's Commissar of Foreign Affairs Georgi Vasil'evich Chicherin. ${ }^{84}$ She also joined Mikhail Ivanovich Kalinin, Chairman of the Central Executive Committee of the All-Russian Congress of Soviets, and "First Lady of the Land" Ekaterina Ivanovna Kalinina for a month-long journey through the famine-ridden regions along the Volga on board a train and a boat specifically equipped for propaganda purposes. ${ }^{85}$ Beatty claimed that while travelling to the "fringes of Russia," she saw more of the country-primitive, suffering, despairing - than she had hoped to see in a year. ${ }^{86}$ She learned something about it, "that Moscow could never teach." ${ }^{87}$ As during her first Russian sojourn, Beatty explored the country though individual accounts of ordinary Russians whom she encountered on her way down the Volga River to its mouth at the Caspian Sea. She observed the life of the young Socialist state from a chaynaya - a Russian version of an old English inn-considering it the best spot for learning about people and the revolution. Struck by radical changes to social organization and human experiences, she wrote that "every life has been jolted out of its accustomed rut." No one, according to Beatty, was "what he was four years ago." Some were more so, and some were less, but all "were different." 88 Riding a springless "back-breaking telega (dray cart)" through "a still, gray, sad world," she contemplated an "endless procession of lonely men and women ... trekking across plains and through forests - learning to endure." Four years into the revolution, "that is all that Russia has learned." Depicting pervasive "misery and want," Beatty blamed both drought and Bolshevism. ${ }^{89}$

${ }^{84}$ See, for example, Bessie Beatty, "Message to Americans from the Man Who Rocked the World," Hearst's International 41 (April 1922): 22-23, 90; Bessie Beatty, "They Lie about Me in America," Hearst's International 42 (July 1922): 32-35; Bessie Beatty, "Chicherin," The New Republic (17 May 1922): 335-38.

${ }_{85}$ See, for example, Bessie Beatty, "A Peasant on a Painted Train. Here is Russia-I," Hearst's International 40 (December 1921): 12, 88-89; "Beatty, Bessie," in Great Soviet Encyclopedia, a translation of the third edition, vol. 3 (New York: Macmillan, INC., 1973), 87.

${ }^{86}$ Beatty, "A Peasant on a Painted Train," 12.

${ }^{87}$ Bessie Beatty, "Russia at Home," Good Housekeeping 74, no. 2 (February 1922):123.

${ }^{88}$ Bessie Beatty, "Marusha of the Market Place," Good Housekeeping 74, No. 3 (March 1922): 22.

${ }^{89}$ See, for example, Bessie Beatty, "Marusha of the Market Place," Good Housekeeping 74, no. 3 (March 1922): 22-23, 145-47, or Bessie Beatty, "The Milkwoman of Moscow," Good Housekeeping 74, no. 4 (April 1922), 60-61, 201-06. 
Yet she continued advocating for normalizing American relations with the Soviet regime. When in 1922, the Women's International League for Peace and Freedom (WILPF) created a Women's Committee for Recognition of Russia, she served as one of its executives, along with such formidable women as American suffragists Lucy Gwynne Branham, suffrage, peace and civil rights activist, Belle Case La Follette, and writer Abby Osborne Rust Russell, the wife of socialist politician Charles Edward Russell, among others. Although the Committee did not succeed in persuading the Harding Administration to change America's Russia policy, it generated enough political pressure to bring the issue to public attention, arguing that establishing diplomatic ties with the Soviet Union would be, above all, "a humanitarian measure" essential for sustaining world peace..$^{90}$

From a Russia "grimly struggling to sustain life," Beatty travelled to a "hectically pursuing pleasure" Constantinople. Sharing her impressions in magazine articles, she renounced "definite preconceived ideas" about the country spawned by propaganda, and contemplated the role of a new Turkey in the post-war "economic readjustment of the world." ${ }^{\prime 91}$

In 1924, Beatty was in England covering the new Labour government of Ramsay MacDonald, then motored across continental Europe, joined by British novelist I.A.R. Wylie, suffragette and scientist Rachel Barret, and one of their friends. The four women visited the "oldest and quaintest living republic of Andorra," where they were greeted by its "ruler." 92 Upon her return to the States, Beatty went to Hollywood to work with screen writer and producer David O. Selznik. In 1926, she married British actor William Sauter, and the couple spent time in Los Angeles, where Beatty continued to write for Metro-Goldwyn-Mayer Studios. In 1927, she co-authored a play with a reformed criminal, a "graduate of five penitentiaries" and Fremont Older's protégé, Jack Black. Originally entitled Salt Chunk Mary, the play was a dramatization of Black's best-selling You Can't Win (1926) - an autobiography of a turn-of-the-century vagabond and burglar, therein contemplating the outlaw life and the futility of the criminal justice system. ${ }^{93}$ In 1932, it was staged on Broadway under the title Jamboree. Beatty was also involved in philanthropic work on behalf of unemployed actors, running the Actors' Dinner Club, a place where they "could get a meal and be entertained without the feeling of being charity cases." $" 94$

${ }^{90}$ For more information about the Committee, see Katherine A.S. Siegel, "The Women's Committee for the Recognition of Russia: Progressives in the Age of Normalcy," Peace and Change 21, no. 2 (July 1996): 289-317.

${ }_{91}$ Bessie Beatty, "Bogy-man of the Bosporus," Century 104 (September 1922): $705-$ 706.

92 See Bessie Beatty, "Onaway to Andorra," Good Housekeeping 81, no. 2 (August 1925): 34-35, 96, 98.

${ }_{93}$ Bestseller in its own right, the book, that was first released in 1926 by MacMillan, found popularity again when it was republished more than 60 years later with a foreword by William S. Burroughs, who claimed that it was a major influence on him and his creative work.

${ }^{94}$ Current Biography, Biography Reference Bank, "Beatty, Bessie" (The H. W. Wilson Company, 1944), https://tinyurl.com/y8e9jhy3. 


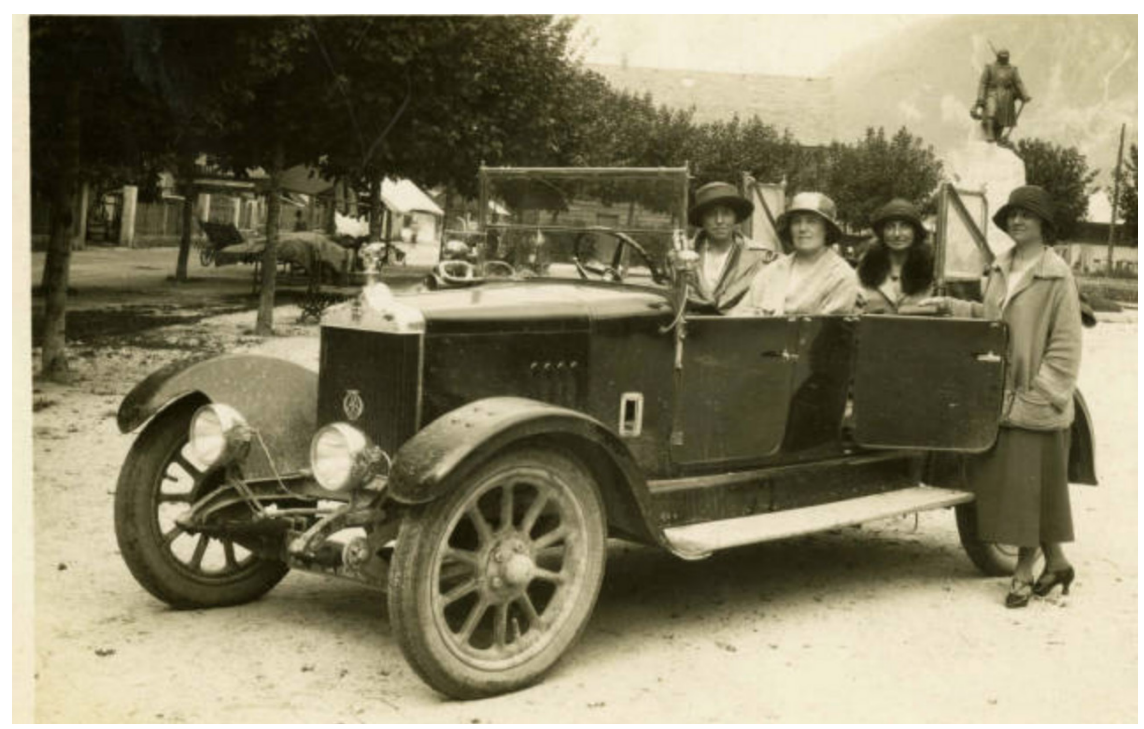

Figure 6. Four women on a European trip. "Miss Wylie at the wheel, Miss Barrett beside her in the rear Miss Wittler. Bessie Beatty is standing." 1924. Courtesy of Occidental College and The Beatty Family.

Beatty never missed an opportunity to be actively involved in social life and participate in various organizations. With the establishment of the National Recovery Administration in 1933, she was invited by the clothing industry to raise consumers' awareness of union-made goods, and handled public relations as a director of the National Label Council. ${ }^{95}$ Later Beatty engaged in publicity work for welfare and cultural groups, such as the Museum of Costume Art, the Greenwich House, the Neighborhood Playhouse School of the Theatre, New York State Commission for the Blind, and the Spanish Child Welfare Association. During the 1932 and 1936 presidential elections, she ran public affairs for the women's division of the New York State Democratic Committee. ${ }^{96}$ Whenever she could, Beatty contributed to community organizing and worked with immigrants who came to New York with the hope of finding a better life for themselves and their children. She wrote press releases for the Greenwich House, which became an integral part of the surrounding largely Italian neighborhood, drawing attention to such issues as employment, better living accommodations, and problems with government agencies. ${ }^{97}$

In 1939, as an American Secretary of the International P.E.N. Club, Beatty organized and directed the World's Congress of Writers at the World's Fair in New York. ${ }^{98}$ Later that year, when she was on her way to Stockholm to attend the

95 "Bessie Beatty, 61, Commentator, Dies."

${ }^{96}$ Current Biography, Biography Reference Bank, "Beatty, Bessie."

${ }^{97}$ See Bessie Beatty's Press Releases and Related Materials, Greenwich House Records, Series III, Programs, Subseries A: Departments and Activities, Sub-subseries 46: Publicity, 1939-1940. TAM.139, Box: 25, Folder: 70. Tamiment Library and Wagner Labor Archives, New York University.

98 "Bessie Beatty, 61, Commentator, Dies." 
P.E.N. congress, she received the news about the German invasion of Poland. Her ship was rerouted to Newcastle, where Beatty spent a month covering life in Great Britain at the outbreak of war. A few months after her return to the United States, she went to Mexico as a reporter for the New York Post. ${ }^{99}$

In 1940, Beatty realized a long-time dream, becoming host of a daily women's radio show on the Voice of New York (WOR), that ran until her death seven years later. Among Beatty's guests were actors, writers, prominent politicians, and such public figures as Eleanor Roosevelt. The show was enormously successful, and Beatty became a "household voice," delivering daily topics of interest for listeners of every economic strata, from all walks of life, many of whom were men. During the Second World War, she drew her audience's attention to ways in which they could contribute to the collective effort, appealing to blood donors, and calling for victory gardens, rationing and war-bond sales. ${ }^{100}$

While Beatty used the air waves to make her own contribution to victory, she never ceased her opposition to war, the heavy toll of which she first witnessed a quarter -century before, when she reported from the Russian front, repeatedly exposing the ubiquitous despondence and loss that transcended borders and adversarial front lines. Raging warfare spares no one from its horrors, from physical suffering, and traumatic internal strife. The humanist has always prevailed in Beatty, as she has denounced the anguish and blood lust, striving for "the muddled old world" to be remade "upon a basis of human freedom and safety." "An advocate for sustaining peace, in 1943, Beatty was awarded the Women's International Exposition medal for her efforts to promote understanding among the nations. ${ }^{102}$ In 1945, when world leaders gathered in San Francisco for the United Nations Conference on International Organization, Beatty dedicated a number of articles to the historic meeting and covered it in her daily broadcasts. ${ }^{103}$

Bessie Beatty died on 6 April 1947, following a heart attack, at the height of her popularity. ${ }^{104}$ Following her death, however, Beatty and her work passed into oblivion. Hopefully, the recent centennial of the Russian Revolution, the growing curiosity stemming from the unfolding hysteria around the current alleged Russian interference in US internal affairs, and the enhanced body of scholarship in the history of the feminist movement, will help revive an interest in her eventful life, pioneering work as an early female journalist, and unbroken faith in humanity. The forthcoming first republication of The Red Heart of Russia, after a century of obscurity, may be a first step in that direction.

\footnotetext{
${ }^{99}$ Current Biography, Biography Reference Bank, "Beatty, Bessie."

100 "Bessie Beatty, 61, Commentator, Dies."

${ }^{101}$ Beatty, The Red Heart of Russia, 114.

${ }^{102}$ Latrobe Carroll, "A Voice in Your Home," in Topflight: Famous American Women,
} ed. Anne Stoddard (Edinburgh, New York, Toronto: Thomas Nelson \& Sons, 1946), 209.

${ }^{103}$ See, for example, her article entitled "Women of One World," Independent Woman 24 (24 July 1945), 178-180.

104 "Bessie Beatty, 61, Commentator, Dies." In 1946, a biographical sketch of Beatty's life by Latrobe Carroll was included in a book entitled Topflight: Famous American Women, edited by Anne Stoddard. See, Carroll, “A Voice in Your Home,” 199-211. 


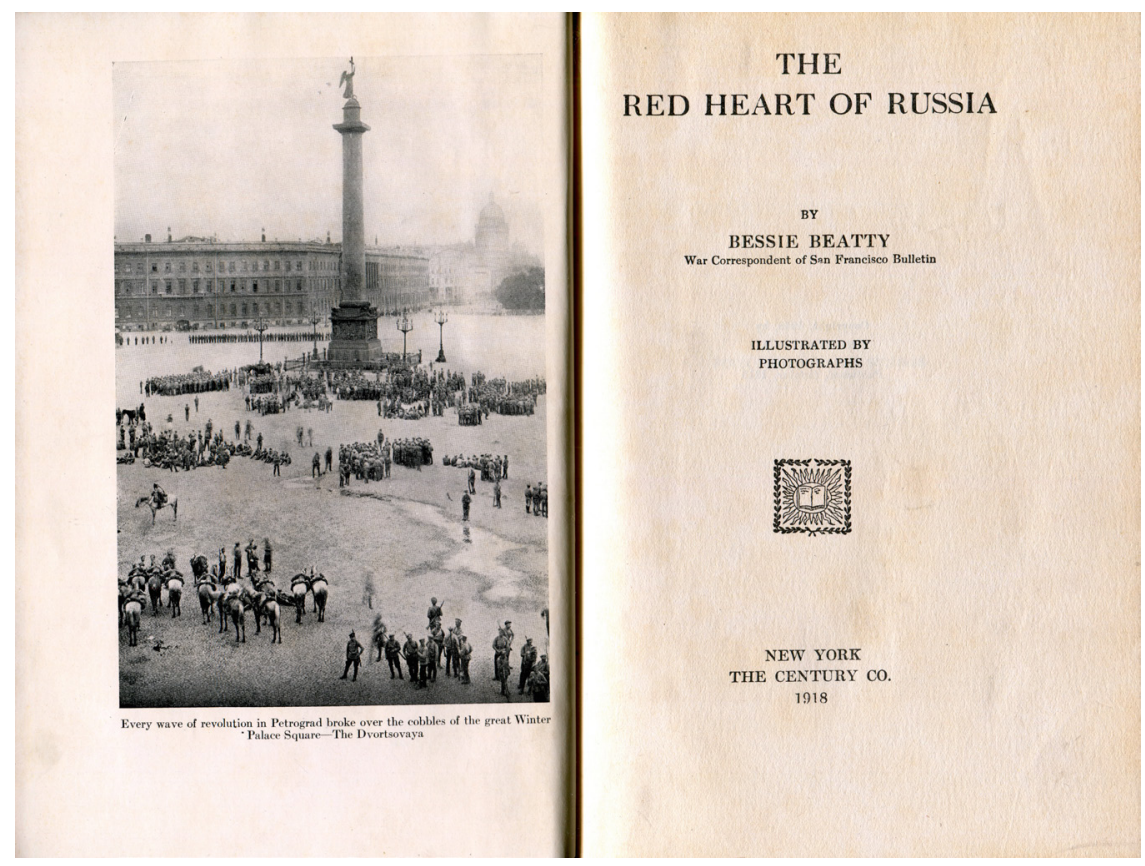

\section{About the Author}

A native of St. Petersburg, Russia, Lyubov Ginzburg received her M.A. from St. Petersburg State University and a Ph.D. from the University of Kansas. With research interests in the history of Russian-American relations, Dr. Ginzburg has dedicated her academic career to exploring and analyzing the broad venues of public diplomacy, cultural influences, and social interactions between these two nations. Presently she is revising for publication her dissertation, entitled: Confronting the Cold War Legacy: The Forgotten History of the American Colony in St. Petersburg (A Case Study of Reconciliation). She is also an editor for a Slavica Publishing project dedicated to the Russian Revolution centennial, annotating a first-hand witness account of revolutionary events in Russia, authored by Bessie Beatty, an American journalist, women's rights advocate, writer, radio host, and activist.

For two decades, Dr. Ginzburg has taught graduate and undergraduate-level courses and seminars at universities in Russia, the United States and Europe, in Sociology, Communication Studies, American Studies, Slavic Languages and Literatures, and Western Civilization. She has also taught advanced Russian to UN language professionals. 